\title{
表面拡散と粒界拡散に基づく電子パッケージ内アルミ配線の ストレス・マイグレーション破壞の数值シミュレーション*
}

\author{
北村隆 行*1, 大谷隆一*1, 山中哲哉*2 \\ Numerical Simulation of Stress-Induced Failure \\ in Aluminum Conductors of a Microelectronic Package based \\ on Surface and Grain Boundary Diffusion
}

Takayuki KITAMURA, Ryuichi OHTANI and Tetsuya YAMANAKA

\begin{abstract}
The stress-induced failure in an aluminum conductor of a microelectronic package was investigated in terms of diffusion along the surface and grain boundary. The mechanism of the growth of groove, which initiated at and progressed along a grain boundary perpendicular to the stress at elevated temperature, was proposed and the failure process was numerically simulated. The grooving process was found to be sensitive to thermal stress as well as the diffusion ratio, $F=$ (grain boundary diffusion)/(surface diffusion). The active grain-boundary-diffusion brought about a crack-like groove at high magnitudes of $F$ and/or stress, whereas the low magnitudes led to a $\mathrm{V}$-shaped groove and marked thinning of the conductor.
\end{abstract}

Key Words : Numerical Analysis, Thermal Stress, Diffusion, Aluminum Conductor, LSI, Electronic Package, Stress-Induced Migration, Grain Boundary Grooving, Surface Diffusion, Grain Boundary Diffusion

\section{1. 緒晋}

電子パッケージのアルミ配線は高集積化のため細線 化が追求され, 線幅 $1 \mu \mathrm{m}$ 以下となっている.これに伴 ってストレス・マイグレーションやエレクトロ・マイ グレーションと呼ばれる現象によって配線の破損・破 断が発生することが知られるようになり, その防止が パッケージの信頼性確保のための重要な課題の一つと なってきている(1) (8). 図 1 はストレス・マイグレーシ ヨンによるアルミ配線の破断の一例である.ところが, ストレス・マイグレーションは比較的最近発見された 現象(1) (5) であって，その機構は明らかになっていな

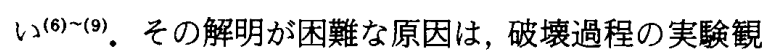
察が困難であることに加え, 現在までに研究されてき た機器部材とは異なる微小部材特有の破壊機構である ためと考えられる。

本研究では, ストレス・マイグレーションによる微 視的粒界破壊機構として表面拡散と粒界拡散に基づく 粒界溝成長 (grain boundary grooving)を提案する。 また, 同機構による粒界溝成長の数值シミュレーショ

\footnotetext{
* 原稿受付 平成 5 年 1 月 14 日.

*1 正員, 京都大学工学部（606-01 京都市左京区吉田本町).

*2 京都大学大学院.
}

ンを行う。

2. ストレス・マイグレーションの

\section{破圜機構の提案}

$2 \cdot 1$ 表面拡散による粒界溝の発生・成長 固体表 面の拡散による原子のフラックス $J_{s}$ は, 次式のよう に表面に沿った化学ポテンシャル される(10).

$$
J_{s}=-\left(D_{s} \delta_{s} / \Omega k T\right) \cdot \partial \mu / \partial s
$$

ここで， $D_{s}$ は表面拡散係数， $\delta_{s}$ は表面拡散層の厚さ， $\Omega$ は原子容積, $k$ はボルツマン定数, $T$ は絶対温度, $s$ は表面に沿った距離である.表面の化学ポテンシャ

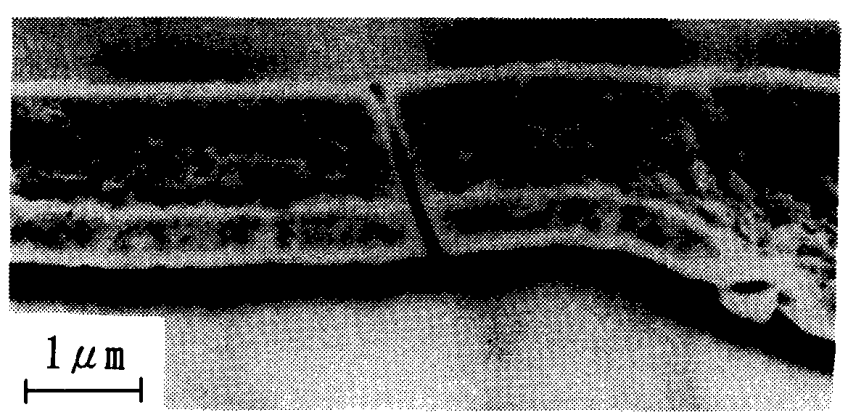

図 1 ストレス・マイグレーションによるLSI パッケージ 内アルミニウム配線の破断例 
ルは表面形状に依存し, 表面の曲率 $x$ の関数として

$$
\mu=\mu_{0}-\Omega \gamma_{s} \chi
$$

と表される(11). ただし， $\mu_{o}$ は平面のポテンシャル， $\gamma_{s}$ は表面エネルギーである。すなわち，物体は曲率 $x$ が 一定の球状になるように表面拡散が起こる。また，質 量保存則とこれらの式を組合せると，表面の各位置に おける垂直方向相対変形速度 $V_{n}$ は

$$
V_{n}=-\left(D_{s} \delta_{s} / \Omega k T\right) \cdot \partial^{2} x / \partial s^{2}
$$

と与えられる。

ここで, 図 2(a)に示すような表面垂直方向に粒界 (破線)を有する固体表面を考える，粒界がなければ表 面のいたるところで化学ポテンシャルは一定であり， 表面拡散による形状変化は生じない。一方, 粒界と表 面の会合点では, 熱動力学的局所エネルギーバランス より表面は図 2(b)に示すような

$$
2 \gamma_{s} \cdot \cos \psi=\gamma_{b}
$$

を満たす平衡角 $\psi$ を形成する。なお， $\gamma_{b}$ は粒界自由工 ネルギーである，したがって，会合点近傍では曲率 $x$ は零ではないため, 図2(b)に矢印で示すような表面 拡散による原子の流れが誘起される。この流れによっ て粒界に沿って Thermal grooving と呼ばれる開口 の大きい溝が形成される(12)。この場合, 溝は初期には 高速で成長するが, 成長とともに減速されるため，か なり微小な要素といえども強度的な問題となることは ない.しかし，次節に述べるように引張応力が作用す る場合には成長の加速が生じるので，このような粒界 溝は微小要素を破壊に導く欠陥の端緒となり得る.
に沿った原子の拡散は,

$$
J_{b}=-\left(D_{b} \delta_{b} / \Omega k T\right) \cdot \partial \mu / \partial x
$$

に支配される(10).ここで, $J_{b}$ はフラックス, $D_{b}$ は粒界 昖散係数， $\delta_{b}$ は粒界厚さ， $x$ は粒界に沿った距離であ る. 化学ポテンシャル $\mu$ は垂直応力 $\sigma$ に依存し, 次式 のように表される(13).

$$
\mu=\mu_{o}-\Omega \sigma
$$

$\mu_{0}$ は無負荷時のポテンシャルである. 質量保存則 $\partial J_{b} / \partial x+\dot{\delta}=0$ は式(5)，(6)を用いて次式となる.

$\left(D_{b} \delta_{b} \Omega / k T\right) \partial^{2} \sigma / \partial x^{2}+\dot{\delta}=0$

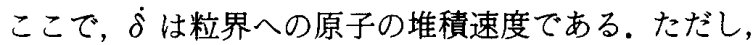
粒界上に作用する応力は $\sigma$ のであって，他の応力成 分は零とする，高温クリープにおける物体内部の粒界 キャビティの成長は，このような応力に誘起された粒 界拡散によってもたらされることが知られており， Hull と Rimmer をはじめとして数多くのキャビティ 成長解析が本式に基づいて行われてきた ${ }^{(13) \sim(15)}$.これ らの解析を参考に，近似的に堆積速度 $\dot{\delta} は$ 粒界に沿 って一様である (rigid grain の仮定)と考えることが できる。

図 2(c)のように粒界溝に垂直な方向に引張応力が 作用する場合には，粒界拡散によって原子が溝先端か ら粒界方向に流出する。したがって，表面拡散に加え て粒界拡散による原子流出の重畳によって粒界溝成長 は加速される。ここで, 粒界溝の先端における化学ポ テンシャルと原子のフラックスの連続性より次の関係 が得られる。

$$
\sigma_{o}=\gamma_{s} x_{\mathrm{tp}}
$$

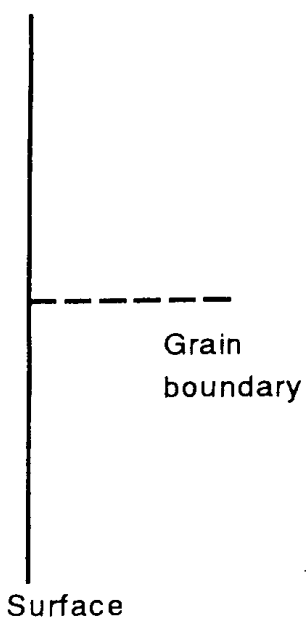

（a）表面と粒界の会合点のモデル図

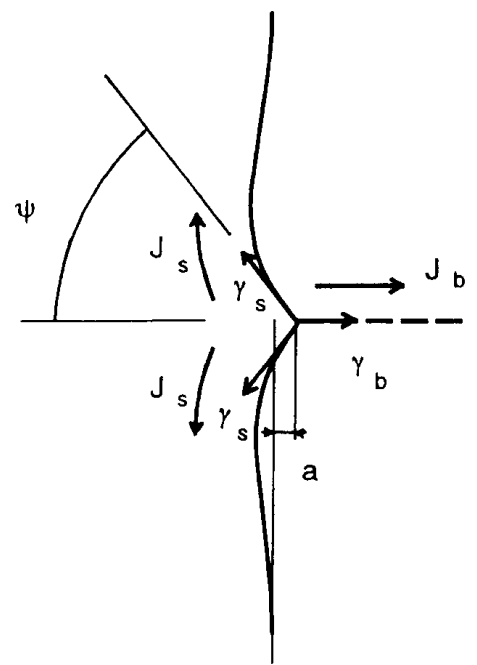

（b）表面㹡散による粒界湽形成の 説明図

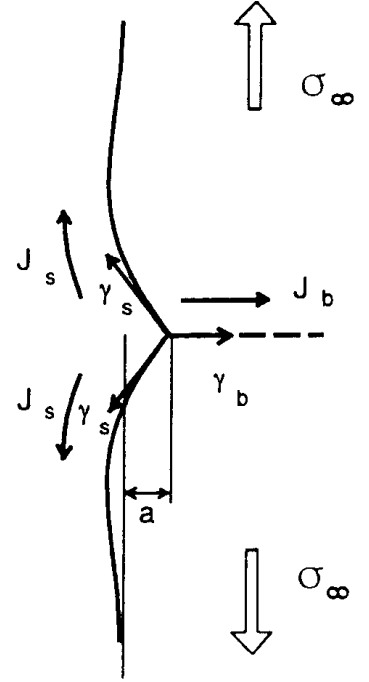

（c）表面拡散と粒界拡散の競合に よる粒界渾形成の説明図

図 2 表面拡散および粒界拡散による粒界溝形成の説明図 
$\sigma_{o}^{\prime}=\left(2 k T / D_{b} \delta_{b}\right) \cdot(\partial x / \partial s)_{\mathrm{ttp}}$

$\sigma_{o}, \sigma_{o}^{\prime}, x_{\mathrm{ttp}},(\partial x / \partial s)_{\mathrm{tip}}$ は，それぞれ粒界溝先端におけ る粒界垂直応力, その $x$ 方向 (結晶粒界に沿う方向)の 偏微分, 溝先端の曲率およびその表面に沿った距離 $s$ に対する偏微分である。

表面拡散に比べて粒界拡散が活発である場合 $\left(D_{b} \delta_{b} / D_{s} \delta_{s} \gg 1\right)$ には，粒界と表面の会合点近傍原子は 粒界に吸収されるため, 表面拡散による溝の開口より 樑さを増すほうが速い。したがって, 粒界溝は粒界に 沿ったき裂状の形になると推定される。一方，表面拡 散が活発である場合 $\left(D_{b} \delta_{b} / D_{s} \delta_{s} \ll 1\right)$ に, Thermal grooving と同様の開口の大きな粒界溝が形成される と考えられる。実際の粒界溝成長は，表面拡散と粒界 拡散の競合によりその形状や成長速度等が決定され る.

クリープキャビティは物体内部の粒界析出物等を核 に発生することが知られている(16)(17) が, 粒界溝は表 面と粒界の会合があるだけで発生する，すなわち，粒 界溝の場合には特別な核生成は不要であり，部材が高 温にさらされた瞬間に発生し，ただちに成長を開始す る。微小要素はその体積に比して表面積が大きいため, 粒界溝はその破損寿命に重大な影響を及ぼすと考えら れる。<smiles>[O+]=c1cc1</smiles>

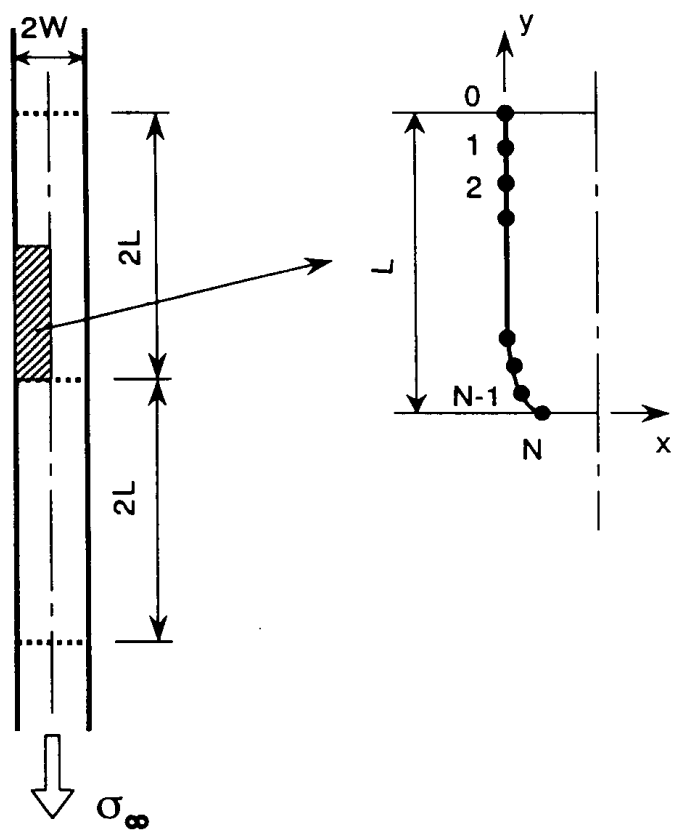

（a）バンブー構造を有する（b） シミュレーションを行った アルミニウム配線のモデル

配線領域と踓散化の説明図

図 3 アルミニウム配線モデル
3. 粒界溝成長の数值シミュレーション

粒界溝の成長は，拡散方程式 [式(3)，（7 ）], 粒界 溝先端における条件 $[$ 式(4)，（8），(9)]，外部境界 条件より求められる. 本章では, 差分法によりその粒 界溝成長の数值シミュレーションを行う.

$3 \cdot 1$ シミュレーション万法 図3(a)はモデル 化した Bamboo 構造を有する多結晶配線を示す.この 構造はエレクトロマイグレーションの抑制には効果が あるが, ストレス・マイグレーションには依然として 大きな問題があることが知られている(7)(8). また, 電子 パッケージ内配線には保護膜との熱膨張差により引張 りの熱応力が負荷される(6) (9). そこで, 図のように粒 界は周期的に配線を横断するとし, 軸方向に引張応力 $\sigma_{\infty}$ が負荷された二次元配線を解析対象とした。

式（７）の微分方程式を式 (8)，(9)および

$d \sigma / d x=0$ at $x=W($ 配線中央；配線幅は $2 W$ )

$W \sigma_{\infty}-\gamma_{s} \sin \phi=\int_{a}^{W} \sigma d x$

の条件のもとで解くと, 粒界拡散による粒界溝からの 原子の流出は次の溝端での曲率に関する方程式に集約 することができる.

$$
\begin{gathered}
x_{\mathrm{tlp}}=\left(\sigma_{\infty}-\sin \psi\right) /(1-a / W) / \gamma_{s} \\
-(2 / 3)(1-a / W) F(\partial x / \partial s)_{\mathrm{ttp}}
\end{gathered}
$$

ここで, $F$ は粒界拡散と表面拡散の比(拡散比)

$$
F=D_{b} \delta_{b} / D_{s} \delta_{s}
$$

である，すなわち，式(11)のもとで式（3）の表面拡散 の微分方程式を解けばよいことになる。そこで, 問題 の対称性を考慮して図 3(b)に示す $1 / 4$ 領域の配線表 面を 50〜200 個の点に離散化して計算を行った．ただ し, 各変数は次式によって無次元化して計算を行っ た。

$$
\begin{aligned}
& \bar{t}=t\left(D_{s} \delta_{s} \Omega \gamma_{s}\right) /\left(k T W^{4}\right) \quad \cdots \ldots \ldots \ldots \ldots, \ldots \ldots(13 \cdot \mathrm{a})
\end{aligned}
$$

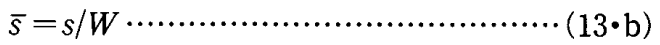

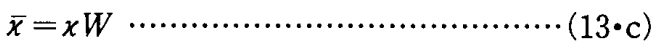

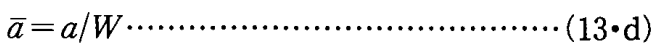

$$
\begin{aligned}
& \bar{v}_{n}=v_{n} k T W^{3} /\left(D_{s} \delta_{s} \Omega \gamma_{s}\right) \quad \cdots \cdots \cdots \cdots \cdots \cdots \cdot(13 \cdot \mathrm{e})
\end{aligned}
$$

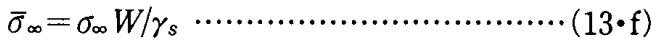

シミュレーションは次の手順に従って行った。まず, 配線表面の点 $i$ における曲率 $\bar{\chi}_{i}$ を点 $i-1, i, i+1 の$ 3 点の座標をとおる円の半径の逆数として求める.た だし，粒界溝先端における曲率 $\bar{\chi}_{N}$ は式(11) を無次元 化した次式より計算した。

$$
\begin{aligned}
\bar{x}_{N} & =\left[\left(\bar{\sigma}_{\infty}-\sin \phi\right) /\left(1-\bar{x}_{N}\right)\right. \\
& \left.+(2 / 3)\left(1-\bar{x}_{N}\right) \cdot \bar{x}_{N-1} / F /\left(\bar{s}_{N}-\bar{s}_{N-1}\right)\right] \\
& /\left[1+(2 / 3)\left(1-\bar{x}_{N}\right) / F /\left(\bar{s}_{N}-\bar{s}_{N-1}\right)\right] \cdots \cdots(14)
\end{aligned}
$$


式 $(3$ ) より任意の点 $i$ の無次元化した垂直変位速度 $\bar{v}_{i}$ は次式より求められる.

$$
\begin{gathered}
\bar{v}_{i}=\left[\left(\bar{x}_{i+1}-\bar{x}_{i}\right) / \bar{s}_{i+1}-\left(\bar{x}_{i}-\bar{x}_{i-1}\right) / \bar{s}_{i}\right] \\
\quad /\left[\left(\bar{s}_{i+1}+\bar{s}_{i}\right) / 2\right] \ldots \ldots \ldots \ldots \ldots \ldots \ldots \ldots \ldots \ldots \ldots \ldots \ldots \ldots \ldots \ldots \ldots \ldots \ldots
\end{gathered}
$$

点 $i$ の座標を $\left(\bar{x}_{i}, \bar{y}_{i}\right)$ とすると, 微小時間 $\Delta \bar{t}$ 経過後 の表面の座標 $\left(\bar{x}_{i}^{\prime}, \bar{y}_{i}^{\prime}\right)$ は,

$$
\left(\bar{x}_{i}^{\prime}, \bar{y}_{i}^{\prime}\right)=\left(\bar{x}_{i}+\bar{v}_{i} \Delta \bar{t} \cdot \sin \theta_{i}, \bar{y}_{i}+\bar{v}_{i} \Delta \bar{t} \cdot \cos \theta_{i}\right)
$$

$\tan \theta_{i}=-\left(\bar{y}_{i+1}-\bar{y}_{i-1}\right) /\left(\bar{x}_{i+1}-\bar{x}_{i-1}\right)$

表 1 シミュレーション条件

\begin{tabular}{|c|c|c|}
\hline $\begin{array}{c}\text { Simulation } \\
\text { No. }\end{array}$ & $\begin{array}{c}\text { Diffusion } \\
\text { ratio } \\
\text { Fion }\end{array}$ & $\begin{array}{c}\text { Hondimensional } \\
\text { stress } \\
\bar{\sigma}_{\infty}\end{array}$ \\
\hline 1 & 0.1 & 7 \\
\hline 2 & 1 & 5 \\
\hline 3 & 1 & 7 \\
\hline 4 & 1 & 10 \\
\hline 5 & 1 & 50 \\
\hline 6 & 10 & 7 \\
\hline 7 & 100 & 7 \\
\hline 8 & 100 & 10 \\
\hline 9 & 10000 & 3 \\
\hline 10 & 10000 & 7 \\
\hline 11 & 10000 & 10 \\
\hline 12 & 10000 & 50 \\
\hline
\end{tabular}

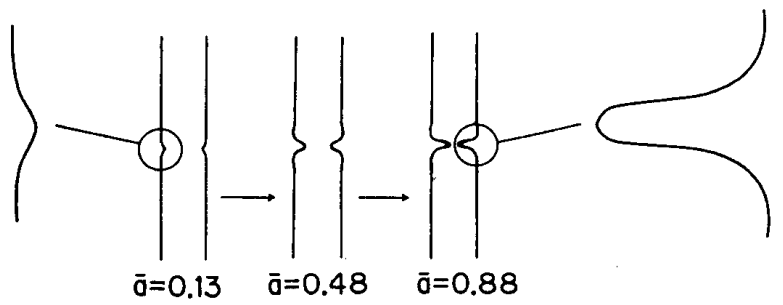

(a) $\quad F=10^{4}$ and $\bar{\sigma}_{\infty}=7$

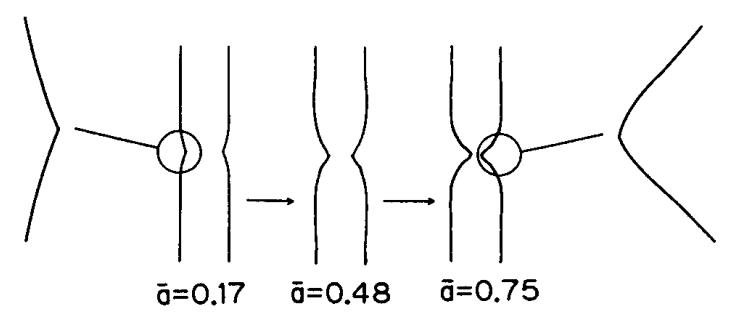

(b) $\quad F=0.1$ and $\delta_{\infty}=7$

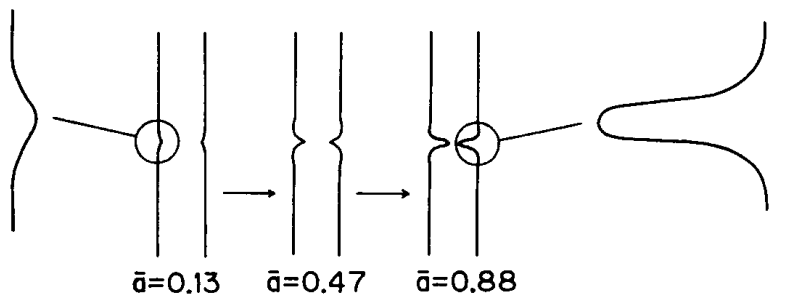

(c) $F=1$ and $\bar{\sigma}_{\infty}=50$

図 4 シミュレーションより得られた粒界溝形状の変化
より計算できる.ここで, 計算精度を考虑して, 全点に おいて1ステップにおける変位增分 $\bar{v}_{i} \Delta \bar{t}$ が 0.001 以下となるように $\Delta \bar{t}$ を十分小さく設定した，满先端 の座標は $\left(\bar{x}_{N-1}^{\prime}+\bar{y}_{N-1}^{\prime} / \tan \psi, 0\right)$ とした.ここで得られ た新座標をもとに上述の過程を綝返して成長過程を求 めた。また，隣接点間隔が初期間隔の 2 倍を越える場 合には，新たな点をその中央に導入した。なお，クリー プキャビティ成長について同様の数值シミュレーショ ンがNixらによって行われている(15).

計算条件の詳細を表 1 に示す。ここでは, 隣合う二 つの粒界の間隔 $2 L$ が配線幅 $2 W$ に比べて十分大きい (線幅 $2 W$ の 10 倍)場合について計算した.

$3 \cdot 2$ シミュレーション結果および考察 図 4 は シミュレーションより得られた粒界满成長による溝形 状の変化を示す.式(12)の拡散比が大きい場合には(高 $F$ 値)図 (a), 高応力の場合には図 (c)のように, 溝 は粒界に沿ってき裂状に成長している。これに対して, 低 $F$ 值かつ低応力条件下では，図（b)に示すように Thermal groovingに似た開口角の大きな V 形の粒 界溝となっている. 応力や $F$ 值は温度等のパッケージ の製造条件や使用条件に敏感であるが，ストレス・マ イグレーション破損配線の観察より, 使用条件の違い によってき裂状あるいはV 形の溝のいずれかが存在 することが指摘されている(8). なお，配線の応力は非

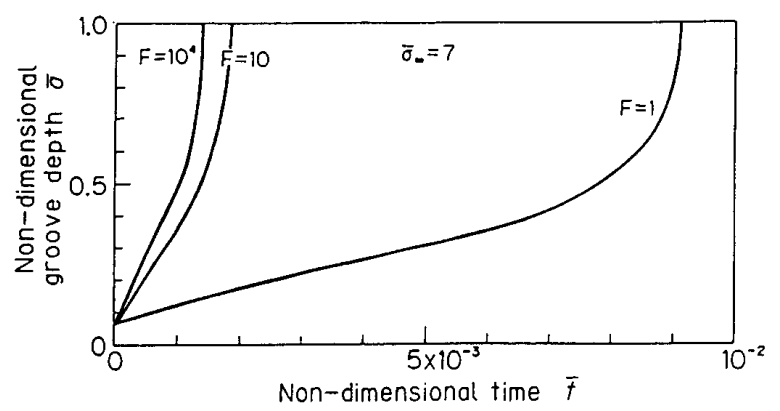

(a) $\quad \bar{\sigma}_{\infty}=7$

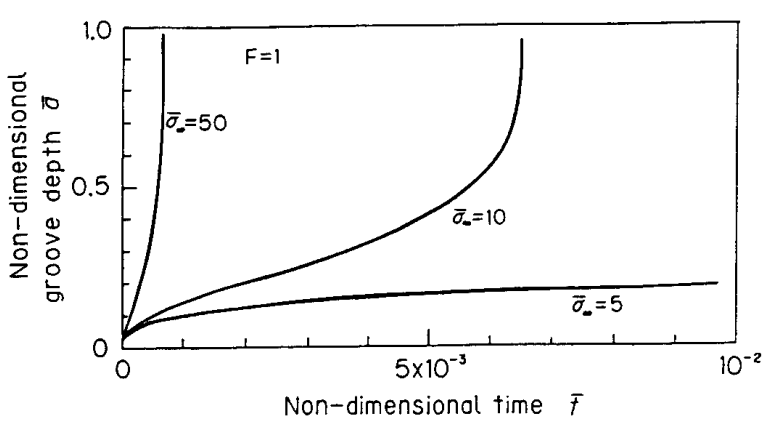

(b) $\quad F=1$

図 5 シミュレーションより得られた粒界溝の 無次元化成長曲線 


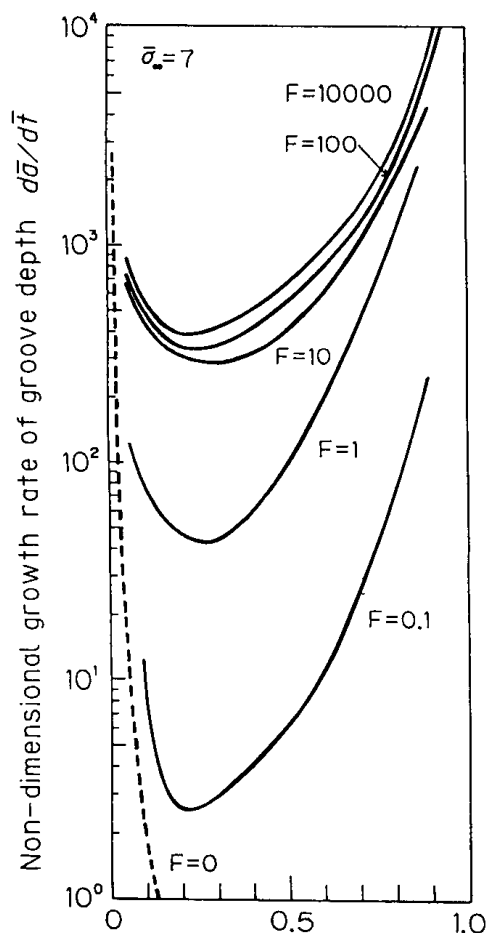

Non-dimensional groove depth $\bar{\sigma}$

(a) $\bar{\sigma}_{\infty}=7$

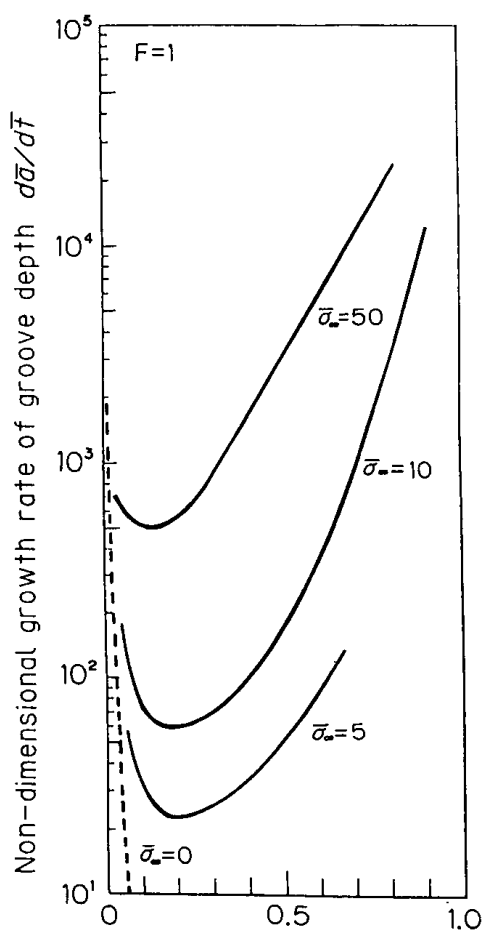

Non-dimensional groove depth $\bar{a}$

(b) $F=1$

図 6 シミュレーションより得られた粒界溝の無次元化成長速度

常に高い場合があることが報告されており(8)，通常の 金属材料では $F$ 值は 100 以下であることを考え合わ せると, 配線に現れるき裂状の溝成長には応力の寄与 が大きいと考えられる。

図 5 と図 6 は粒界湿の成長曲線と成長速度である. いずれの条件においても，粒界溝は初期には高速成長 を示すものの, 成長とともに減速する.しかし，後期に は断面減少による真応力増加のために再び成長が加速 される．また，応力および $F$ 值が大きいほど溝成長は 速く，応力に誘起された粒界拡散により著しく成長が 加速されることがわかる. 図 6 中の破線は無負荷条件 下の清成長速度であり，粒界湴深さ $a$ の時間に対する 変化の解析解 ${ }^{(12)}$,

$$
a=0.7803 \cdot \tan (\pi / 2-\psi)\left(D_{s} \delta_{s} \Omega \gamma_{s} t / k T\right)^{1 / 4}
$$

の時間微分として得られるものである.ここで, $t$ は高 温にさらされた時間であり， $a$ は初期表面位置より測 定した溝深さである，応力が負荷された場合(実線)で も，ごく初期の成長挙動は破線と一致する傾向があ る。すなわち，粒界拡散がかなり活発な条件において も，瑇発生および初期成長は表面拡散に支配されてい ることがわかる.図 4(a) と（c) を詳細にみると，粒界 拡散が活発な条件にもかかわらず初期にはV 形に近 い瑇形状となっており，表面拡散が瑇発生・成長を律

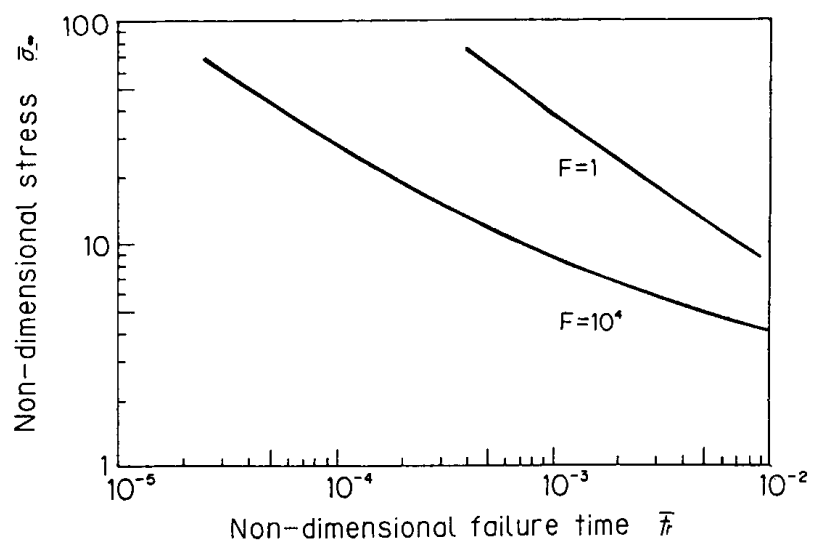

図 7 シミュレーションより得られたアルミニウム 配線の無次元化寿命

速していることを示している.

図 7 は,シミュレーションより求められた配線の破 損寿命を示す。ここで, 配線の破損寿命には粒界渾が 配線を横断する破断時間 $t_{r}$ をとっている. 粒界拡散が 活発となる条件ほど破損寿命は短い。ここで，

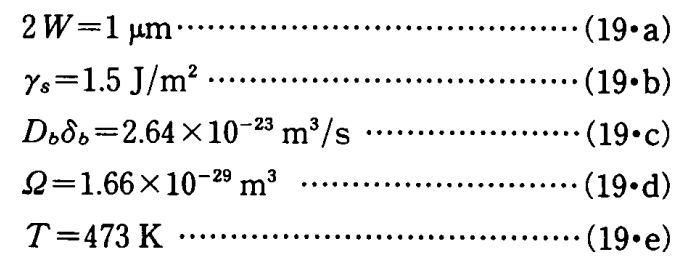




$$
\begin{aligned}
& F=100 \\
& \Sigma=7(\text { 約 } 21 \mathrm{MPa})
\end{aligned}
$$

と設定すると, 本シミュレーションより求められる破 損寿命は約 24 時間となり，粒界溝成長が現実的に大 きな影響を及ほすことが明らかである。ただし，本モ デルでは粒界溝成長に伴う応力緩和の効果を考虑して おらず, 上記の温度等は高めに設定しているため, 実 際の破損寿命はこれより長くなると考えられる。ただ し, 薄膜配線では応力ゃ $F$ 值は製造条件や使用条件 のみならず局所の微視構造に強く依存するため, 配線 の部分によって大きく異なることが予想される，現時 点では,これらの值については正確に求められていな い.また，現実の配線は三軸応力下にあるため，これが 拡散に及ぼす影響を明らかにする必要がある。さらに， 配線長さ (粒界数)を考慮した最弱部分の信頼性解析も 重要になるであろう。

さて, 式(13・a)より本機構による破損時間は配線幅 の 4 乗に比例することがわかる．したがって，配線幅 が $100 \mu \mathrm{m}$ の場合には破損時間は $1 \mu \mathrm{m}$ の場合の $10^{8}$ 倍となって, 現実的には問題とならない. 逆に, $1 \mu \mathrm{m}$ を割ると，寿命は急速に短くなる。すなうち，本機構は サブミクロンの微小部材に特有の破壊機構である。

\section{4. 結}

電子パッケージ内アルミ配線の主要な破損原因のひ とつであるストレス・マイグレーションによる破壊機 構について検討した. また, その破損過程の数値シミ ユレーション方法を行った。得られた主な結果を以下 に要約する。

（1）アルミ配線のストレス・マイグレーション破 壊機構として, 表面拡散と粒界拡散の競合による粒界 溝の成長モデルを提案した。

（2）粒界溝の発生および初期成長は表面拡散が支 配的である。

（3）粒界溝成長は，垂直引張応力に誘起された粒 界拡散により著しく加速される。

（4）粒界拡散が表面拡散より活発な条件下では, き裂状の粒界溝が形成され，逆の場合には溝は開口の
大きな V 形に成長する，また，粒界拡散が活発である 条件 (高 $F$ 值, 高応力) ほど, 溝成長速度は速く, 配線 の寿命は短い。

（5）本研究で提案した粒界溝成長は $1 \mu \mathrm{m}$ 以下の 微小要素特有の高温破壊機構であり，その影響は線幅 寸法の 4 乗に反比例する形で急速に大きくなる.

最後に, 本研究は平成 3 年度文部省科学研究實補助 金総合研究 $(A)$ (研究代表者 東北大学工学部・阿部博 之教授)によって実施した。また，図1の写真は(株)東 芝研究開発センター機械・エネルギー研究所・川上崇 氏より提供を受けた。さらに, 同氏には本研究に関す る電子パッケージ製造・使用上の問題点をお教えいた だいた．合わせて謝意を表する。

\section{文献}

(1) Klema, J., Pyle, R. and Domangue, E., Proc. Int. Reliability Physics Symp., (1984), 1.

(2) Curry, J., Fitzgibbon, G., Guan. Y., Muollo, R., Nelson, G. and Thormas, A., Proc. Int. Reliability Physics Symp., (1984) 6.

(3) Kudou, H., Sawada, K. and Izumi, H., Advances in Electronic Packaging 1992, Proc. of the 1992 Joint ASME/JSME conference on Electronic Packaging, Am. Soc. Mech. Eng., (1992), 713.

(4) Borgesen, P., Korhonen, M. A., Basa, C., LaFontaine, W. R., Land, B. and Li, C.-Y. Materials Reliability Issues in Microelectronics, Material Research Society Symp. Proc., 225(1991), 143, 161.

(5) Lloyd, J. R. and Arzt, E., Materials Reliability in Microelectronics II, M. R. S. S. P., 265(1992), 45.

（6）安食監修, 半導体デバイスの信頼性技術, (1988)，208, 日 科技連刊.

（7）日野出，日本金属学会会報，28-1(1989)，40.

（8）岡林, 応用物理, 59-11(1990), 1461.

（9）手崎 - 金子・蓮沼, Nikkei Microdevices, (19905), 93.

（10）たとえば, Shewmon, P. G., Diffusion in Solids, (1963), McGraw-Hill.

(11) Herring, C., J. Appl. Phys., 21 (1950) 437.

(12) Mullins, W. W., J. Appl. Phys., 28(1957), 333.

(13) Hull, D. and Rimmer, D. E., Philos. Mag., 4(1954), 673.

(14) Chuang, T., Kagawa, K. I., Rice, J. R. and Sills, L. B., Acta Met., 27(1979), 265.

(15) Martinez, L. and Nix, W. D., Met. Trans., A, 13(1982), 427.

(16) Evans, H. E., Mechanics of Creep Fracture, (1984), Elsevier.

(17) Raj, R., Acta Met., 26(1978), 995. 